\title{
Public Policy for Social Innovations and Social Enterprise-What's the Problem Represented to Be?
}

\author{
Jörgen Johansson ${ }^{1, *(1)}$ and Jonas Gabrielsson ${ }^{2}$ \\ 1 School of Public Administration, University of Gothenburg, SE-405 30 Gothenburg, Sweden \\ 2 School of Business, Innovation and Sustainability, Halmstad University, SE-301 18 Halmstad, Sweden; \\ jonas.gabrielsson@hh.se \\ * Correspondence: jorgen.johansson@spa.gu.se
}

Citation: Johansson, J.; Gabrielsson, J. Public Policy for Social Innovations and Social Enterprise-What's the Problem Represented to Be? Sustainability 2021, 13, 7972. https:// doi.org/10.3390/su13147972

Academic Editors: Ingemar Elander and Andrea Pérez

Received: 26 May 2021

Accepted: 13 July 2021

Published: 16 July 2021

Publisher's Note: MDPI stays neutral with regard to jurisdictional claims in published maps and institutional affiliations.

Copyright: (c) 2021 by the authors. Licensee MDPI, Basel, Switzerland. This article is an open access article distributed under the terms and conditions of the Creative Commons Attribution (CC BY) license (https:/ / creativecommons.org/licenses/by/ $4.0 /)$.

\begin{abstract}
Social innovations and social enterprise have been seen as innovative measures to achieve sustainable development. Drawing on an evaluation of a development project on creating social enterprises in Sweden, this article analyzes social innovations as a policy area. The policy area is often described as loaded with ideological contradictions. The aim of the article is to explore underlying premises and discourses in policy implementation aimed at creating social innovations in a comparison between two ideal types on social sustainability-(1) an individual activation strategy (responsibilization of the individual) and (2) a societal equilibrium strategy (balancing social values). The research question is inspired by Carol Bacchi's policy theory and asks what is the problem represented to be? The analysis is carried out at the micro-level as a context-sensitive approach to explore articulations made among actors creating the policy and entrepreneurs participating in a locally organized project. The article contribute with a better understanding of how societal problems and their solutions are discursively determined, with implications for policy makers and project managers active in this policy area. The analysis and findings indicate a significant policy shift during the implementation process. Initially, the policy idea consisted of well-considered ambitions to create a long-term sustainable development. During the implementation of the project, the problem's representation changes gradually in the direction towards individual activation. This transition is driven by pragmatic difficulties of defining the policy area, problems of separating means from ends, and the need to make decisions based on a limited range of information. We conclude by emphasizing the need for reflection on how the social dimension is defined when implementing social innovation strategies. Furthermore, there is a lack of studies of how this policy area can be linked to policies for social sustainability.
\end{abstract}

Keywords: social innovation; social enterprise; policy analysis; problem representation; individual activation; social sustainability

\section{Introduction}

During the last two decades, there have been monumental hopes for social innovation to achieve sustainable development. In 2009, President Obama launched the Social Innovation Fund to support initiatives in doing business differently by promoting community leadership and investments in innovative community solutions. In Japan, social innovation has been a part of the rebuilding efforts following the 2011 nuclear disaster, which left massive destruction on its assets such as the physical and sociopolitical environment. In the United Kingdom, the Office of Civil Society is designed to enrich lives, drive growth, and promote Britain to the world by working in partnerships with civil society, private businesses, and the state. Recently, social innovation has also been included in the EU 2020 strategy for smart, sustainable, and inclusive growth. Public policy efforts in enhancing social innovations and social enterprises have thus been seen as complementary measures to help solve many of the contemporary problems in a situation where pub- 
lic budgets are under pressure, and public policies are suffering from sectorization and fragmentation [1-8].

Drawing on an evaluation of a regional development project on creating new social enterprises in Sweden, this article analyzes social innovations and social enterprises as an emerging policy area. Policies in this field are often described as both dynamic and complex [9-12]. Firstly, scholars and practitioners in the policy field disagree on definitions [13]. Secondly, and despite the conceptual unanimity, social innovations and social enterprises are policy concepts associated with essential hybridity. They exist in a territory in between the for-profit and nonprofit sectors, and they often combine the logics of the spheres of the state, the market (for-profit), and the civil society (including the community and organizations in the third, non-profit sector) [14,15]. This hybridity seems to create ambivalence among policymakers and participating organizations. For example, the introduction of projects enhancing social enterprises is often met with skepticism among stakeholders in the business sector. On the other hand, actors in civil society are constantly playing the role of the energetic proponent. Still, they often experience disappointment in the slow progress of change or, in the worst case, lost opportunities to reach long-term effects. In the middle stands state authorities and municipal actors that try to mediate between, on one side, demands on a market-oriented and commercial approach and, on the other side, claims for acting following social and human values. In other words, the policy area is loaded with ideological conflicts and contradictory ambitions [16-20].

In this article, we will focus on especially one kind of contradiction embedded in the policy field, namely between two opposing perspectives on social sustainability-on one side, an individual activation strategy, and, on the other side, a societal equilibrium strategy. The two strategies will be compared by an ideal-typical comparative analysis that explicates different ways of articulating the policy problem. Firstly, in the activation strategy, social sustainability contains policies that aim at implanting in individuals' the interest to promote their employability, life-long learning, and attaining the "right" attitudes, e.g., flexibility, career aspirations, entrepreneurial mindsets [21]. Secondly, the societal equilibrium strategy is based on policies that aim to create an equilibrium between often contradictory social values, e.g., justice, human development, and security. Strong social sustainability correlates with a high degree of equilibrium between these contradictory values [22]. In Section 3, we will give a more extensive description of the theories and methods of the comparative analysis.

Our inquiry is guided by the following research question: What is the problem represented to be in policies enhancing social innovations and social enterprises and what is silenced in this representation? To address our research question, we will analyze three sub-questions:

- In what ways are the societal reality characterized in the representation?

- What normative assumptions underpin the representation?

- How has the representation of the problem been transformed by policy proposals?

Against this, the overall purpose of the article is to explore central issues in policies aimed at creating social innovations and social enterprises in a comparison between two ideal types representing different approaches to the policy problem. In that way, the comparative analysis will include considerations on issues of power relations among participating actors and producing legitimacy towards beneficiaries, e.g., presumptive entrepreneurs, non-profit organizations, trade unions, and organizations representing economic and social interests.

The comparative analysis will be carried out at the micro-level as we are interested in how local actors "live" the policy area. Our context-sensitive approach enables us to identify and explore articulations made among actors creating the policy and social entrepreneurs participating in locally organized development projects. Moreover, our research question focuses on the underlying premises, assumptions, and discourses in policy implementation [23]. We employ a research design that involves multiple sources of data, such as documents preparing the policy, interviews with project managers and 
social entrepreneurs, as well as participatory observations. By analyzing how the involved actors problematize and motivate the need for creating social innovations and supporting social enterprises, we can collect rich 'bottom-up' articulations subject to ideal-typical comparative analysis.

Our findings suggest that the original intentions articulated at the regional level and expressed in the project application become something partly different as processes and activities become implemented at lower levels in the implementation chain. Our multi-level analysis of the process shows how idealistic ambitions aimed at creating a long-term sustainable development of society are filtered through pragmatic difficulties of defining values and objectives, separating means from ends, and making decisions based on a limited range of information and analysis. Moreover, our findings illustrate how locally organized social enterprising efforts, championed by entrepreneurs in the project, struggle with managing contradictory values, fragmented organizational structures, and scarce resources. In this respect, our findings contribute to literature and research on social sustainability by providing theoretical and empirical insights of issues and challenges involved when creating and implementing social innovations as a specific policy area in a regional setting

The article is organized in the following way. In Section 2 follows a background describing some essential characteristics of the policy area on social innovations and social enterprises. In the following Section 3, we will present the theoretical and methodological framework. In Section 4, the findings are presented, and the research questions are answered. In Section 5, we finally conclude with a discussion of the main findings.

\section{Social Innovation and Social Enterprise-Concepts and Policy Area}

The concepts of social innovation and social enterprises are contested in research as well as in political life [24-27]. Social innovation is often defined as new ideas, products, services, and methods that meet social challenges. These can be climate issues, integration, unemployment, an aging population, and social exclusion [27], or a more developed definition such as:

a novel solution to a social problem that is more effective, efficient, sustainable, or just than existing solutions and for which the value created accrues primarily to society as a whole rather than private individuals. A social innovation can be a product, production process, or technology (much like innovation in general), but it can also be a principle, an idea, a piece of legislation, a social movement, an intervention, or some combination of them (p. 36, [28]).

In this definition, it is explicitly underlined that social innovations accrue primarily to societal issues rather than on individuals and with primacy given to social over economic value creation. Additionally, the understanding of social enterprise remains debated amongst scholars as well as in practice $[14,29,30]$. It is widely diffused that social enterprise encompass organizing efforts with a central mission to have a transforming impact or to create positive social change [31]. However, definitions continue to range from broader to more narrow approaches. Broadly defined, social enterprise refers to innovative activity with a social objective in either the for-profit sector, the non-profit sector, or both. Narrowly, it refers to simply applying market-based skills and commercial activities in the non-profit sector to create social value and addressing social or environmental needs.

The main conceptual problem associated with social innovation and social enterprise as a policy area is finding a basis for determining what is social and what is not. The social denotes very different things; social motivations or intentions, the social as based on ideals in a community, and processes in society that create social value. The social is also commonly equated with the societal problems or challenges it tries to solve [32,33].

Another kind of conceptual orientation asserts that social enterprise has its specificity in that it simultaneously stresses both the process and results in enterprising efforts [14]. Traditional for-profit enterprise is mainly fixated on the result, but social enterprise encompasses values such as participation, solidarity, trust, and learning as important as 
the results. Hence, the intrinsic value of the processes, not only its output or results, is often emphasized in social enterprise development aimed at social innovations [31,34]. An important point of departure in this article is to examine how social innovations and social enterprising efforts differ from more traditional forms of for-profit-based innovation and entrepreneurship. How do the actors motivate the social in their venturing efforts, and what problems do they intend to solve?

During the last two decades, the concepts of social innovation and social enterprise have gained significant recognition as a new policy area within the broader spectrum of industrial development policies in most countries worldwide. Some scholars conclude that this policy area represents a new paradigm that transcends the traditional boundaries between state, market, and civil society $[35,36]$. The paradigm has its roots in at least two kinds of movements. Firstly, it is connected to the cooperative movement and ideas referred to as the social economy [37]. In this context, the term social enterprises were created and defined as enterprises built on three dimensions [38]:

1. Economic dimensions (market orientation, risk taking);

2. Social dimensions (utilization of resources to communities and for welfare provision);

3. Participative dimensions (involvement of users, room for deliberation, transparency).

In this policy context, it is also worth highlighting the EU Social Business Initiative presented in 2011 by the European Commission. The initiative established an EU-level action plan with concrete measures to develop a favorable environment for social enterprises. This initiative is yet another expression of a policy area that is at an emerging stage. In a research report, Defourny \& Nyssens note that initiatives in this policy field are on the rise, and they conclude:

The debate is now on both the public and the private agenda. Indeed, both the public sector and the private sector, each in its own way, are discovering or rediscovering new opportunities to promote, simultaneously, entrepreneurial spirit and the pursuit of the public good (p. 32) [39]. (See also [40])

Secondly, it is connected to an international movement consisting of influential NGOs, foundations, networks, etc., promoting ideas to integrate social innovations in various efforts to enhance social values in economic and societal development. Among the most influential foundations is the Ashoka Foundation, the Schwab Foundation and the Skoll Foundation, which have made large investments in social innovation, often labeled as 'venture philanthropy' [41,42].

These ideas have diffused globally, and in many countries, governments have institutionalized social innovation and social enterprise as a specific policy area. In the Nordic countries, the introduction of policies promoting social innovations is still regarded as embryonic. In a research report presented for the Nordic Council of Ministers, four kinds of shared characteristics are identified in public policies promoting social innovation and social enterprises in the Nordic Countries [43]:

1. The welfare states are an innovative and active partner to develop this policy area.

2. A basic policy idea is that social enterprises are built on co-operation between the public, private, and civil society.

3. The policy area includes much more than activities tied to work integration

4. The policy area function as arenas for citizens' participation, learning and provision of welfare services.

If we look at Sweden, policies enhancing social innovations and social enterprises do not have any specific legal framework or comprehensive documentation (strategies, organizational structures, resources) that illustrate the scope, orientation, and development of social innovations and social enterprises. Policies enhancing this area extend across several policy sectors concerning, e.g., regional growth, industry and trade, labour market, academic research, politics for civil society (see [44,45]). In 2017, the Swedish government launched a strategy on social enterprises-A sustainable society through social enterprise and social innovation [46]. This strategy has one overall goal and five specific areas that will be 
cornerstones in the future development of social enterprises in Sweden. The overall goal is to strengthen the development of social enterprises to better take part in solving challenges in society and contribute to efforts in the public sector to recognizes and make use of social enterprises as valuable actors in a sustainable society. In the strategy, the government identifies five kinds of specific policy measures that aim to coordinate and strengthen a wide range of components that enhance the development of social innovations to:

1. create needs and demands in the public sector to support social innovations,

2. improve the support structure for business counselling,

3. increase knowledge and ability for private and public investments,

4. develop methods for the evaluation of impacts of social innovations,

5. support hubs or network arenas for dissemination of knowledge and research.

As part of the implementation of this strategy, an assignment is given to the Swedish Agency for Economic and Regional Growth to support local and regional initiatives in creating arenas enhancing social innovation and social enterprises [46].

In this article, we will use empirical data from one such project initiative in Southern Sweden to establish an arena for social innovations among local and regional actors. This arena is intended to contribute to greater collaboration, increased employment, more sustainable companies, and solutions to complex societal challenges. Through a number of business loops with presumptive entrepreneurs, the project intends to gather experiences and learning activities to establish a regionally based arena for future development of social innovations.

\section{Methodological Framework}

The methodological framework intends to problematize how actors are participating in a locally organized project express ambitions, problems, and courses of action for developing social innovations. The intention is to interpret the discourses and arguments that dominate in the implementation of these efforts. To accomplish this, we will use Carol Bacchi's policy theory called What's the Problem Represented to be (WPR-analysis) [23,47,48]. The theory helps to ask critical questions and to challenge axiomatically expressed assumptions in various policies.

Essential to the analysis is to regard societal problems and their solutions as discursively determined with meaning, concepts, and institutionally shaped conditions. In the discourses formed in a policy area, e.g., to develop social innovations, specific forms of conceptual frameworks and institutionally determined understandings shape our practices and working methods in the implementation structure [23]. Thus, the WPR-analysis is a methodological tool to critically ask questions on how public policies are created and implemented. The starting point is that when someone puts forward or suggests something about conditions that are considered to be a societal problem, it is also stated what needs to be solved in a particular activity [47].

The methodological framework combines the WPR-analysis with theories based on analysis of ideas and consists of a sequence in three steps. First, we present the empirical setting and data collection. Second, we introduce the methods based on two ideal types of social sustainability. The ideal types frame the analysis how to map or extract expressions and policy representations in the empirical material. Third, we summarize the approach with questions related to the WPR-analysis.

\subsection{Step 1: Empirical Setting and Data Collection}

This article will analyze what is represented as a problem when social innovations and social enterprises are created and implemented as a specific policy area in a regional setting. The policy area is manifested through a regional development project co-funded by the European Regional Development Fund and the County Council to support new social enterprises in the southern part of Sweden. The managing authority tasked to select projects into the funding programme and monitoring implementation is the Swedish Agency for Economic and Regional Growth. 
The core of the project is to offer coordinated, time-compressed training programs to smaller cohorts of participants who seek to develop social ventures. The program is designed to accelerate the venture development process within a given timeframe by means of enterprise-oriented training, coaching, networking events, and seminars. The typical participants are nascent entrepreneurs, and during the program, they meet 1-2 days per week over ten weeks.

We have used various data sources to account for the many parties involved in characterizing the representation of the policy area. In addition, as the creation and implementation of policy is a process that unfolds over time, we have also collected both retrospectives as well as real-time accounts by relevant parties experiencing the phenomenon of theoretical interest. The data collected enables us to analyze how the involved actors articulate the problems to be solved, what kind of assumptions underpin the representations of the problem, how these representations of the problem come about, and any aspects left unproblematic or silenced.

Our empirical analysis rests on four primary sources of data. First, we have collected documents that provide information about policy intentions. Second, we have followed the planning and implementation of the project from its inception, including continuous changes made in the structure and content of the training program, including being present during different occasions in the training program such as kick-offs, training seminars, guest lectures, and networking events. Third, we have conducted focus group interviews with the project team responsible for carrying out the training programs. Fourth, we have conducted interviews with the social entrepreneurs that have followed the training program. A breakdown of the data used in this study is displayed in Table 1.

Table 1. Data breakdown.

\begin{tabular}{cl}
\hline \multicolumn{1}{c}{ Data Type } & \multicolumn{1}{c}{ Details } \\
\hline Documents & $\begin{array}{l}\text { Notes from policy conference, project application, and } \\
\text { progress reports. }\end{array}$ \\
\hline Participatory observation & $\begin{array}{l}\text { Field notes taken to document events, interactions, and } \\
\text { artifacts observed in the social setting of the training } \\
\text { program. }\end{array}$ \\
\hline Interviews with project managers & $\begin{array}{l}\text { Two group interviews have been conducted with the } \\
\text { project managers during the project period. The project } \\
\text { management consist of the CEO of the organization that } \\
\text { 'owns' the project, the project manager, a business coach, } \\
\text { and the project controller. }\end{array}$ \\
\hline Interviews with target group & $\begin{array}{l}\text { Interviews has been conducted with 24 social } \\
\text { entrepreneurs that followed the training program. The } \\
\text { interviews were semi-structured and conducted three } \\
\text { months after completion. }\end{array}$ \\
\hline
\end{tabular}

\subsection{Step 2: Analyis of Policy Representations and Two Ideal Types of Social Sustainability}

Analytically, we intend to map expressions in the empirical material that contrasts two ideal types to achieve social sustainability: an individual activation strategy versus a societal equilibrium strategy. The ideal-typical analysis represents a way of doing social science research in a heuristic way, i.e., a process of making abstractions of reality in its purest imaginable form by capturing the essential characteristics of an empirical phenomenon. However, by definition, the ideal type is a reduction of reality that aims to serve as a yardstick or a framework to facilitate comparisons in a constantly changing societal environment $[49,50]$. When used as a method of comparison, an ideal type enables us to discover the contrasts between ideals and reality. This article will apply two kinds of ideal types that both contain contrasting strategies to contribute to policies for a social sustainable welfare system. 
The ideal types in this analysis are based on diverting assumptions or ideas. According to the political scientist Lindberg [51], ideas in public policies or political ideologies consists of three kinds of representations. In this context, Lindberg has developed a conceptualization, which he describes as a VDP triad; (V) as values or value-judgements; (D) as descriptions or judgements of reality; and (P) Prescriptions or practical proposals for action [51]. Lindberg assert that such VDP-triads

form not only the argumentative, action-guiding and action-directing backbonethe inner structure-of the common ideal-type political ideologies (such as liberalism, conservatism, feminism etc.), but also the manifest or latent inner structure of deliberative political debate, public policy respectively opinion-forming political propaganda (p. 20, [51]).

As with the concept of social innovation, the concept of social sustainability is contested. It is common in the research on social sustainability to problematize the lack of a coherent definition and that the concept has been subordinated to sustainability linked to both ecological and economic development. By utilizing ideal types as a methodological tool we are able to problematize policy representations made by the involved actors in our case.

In the first ideal type-social sustainability as an individual activation strategy-the dominant descriptions concern ideological changes in western societies associated with neo-liberalism and changes in the institutional settings of the welfare state [21], mainly as a change from an emphasis on universal and collective orientations to more individualized and incentive-driven systems. The normative content is based on a bottom-up view where individuals can utilize freedom of choice and a high degree of 'responsibilization'. Public policies should promote models of contractual partnerships between, on the one side, the state and public institutions and, on the other, private actors and organizations in civil society. This means, among other things, policies creating incentive structures, education for lifelong learning, career planning, entrepreneurship, and so on. The policies are directed towards developing strategies for coaching and coping among individuals in the welfare sector [21,52].

In the second ideal type-social sustainability as a societal equilibrium strategy-the leading problematization concerns how the welfare systems are challenged by societal processes such as globalization, digitalization, migration, and urbanization. In general, social development is considered 'wicked' or complex, i.e., that each problem is unique, with no definitive formula, no final solution (rather, processes of trial-and-error), connectivity among several issues, and often based in a local context. The normative principle that guides the strategy is the ability to create an equilibrium between different social values. In one version, [22] used in this article, social sustainability is regarded as an act of balancing three kinds of societal values: justice (distribution of resources as well as inclusion/participation), human development (education, health, quality of life), and security, e.g., crime prevention as well as promotion of social conditions-" proventive security" $[22,53,54]$.

The ideal types displayed in Table 2 will be used as an analytical framework to characterize how involved actors articulate problems in the development process. Firstly, how do the actors express the societal reality that characterizes the project work: Is the interest primarily directed towards overall societal processes, or are there aspects linked to increasing elements of individualization? Second, what normative justifications are expressed by the actors (i.e., on the importance of individual responsibility or norms attached to complex perspectives that weigh in different values)? Thirdly, which policy proposals are advocated by the actors, demands for social policy for coping/coaching among the disadvantaged, or needs for structurally oriented reform processes? 
Table 2. Ideal types in efforts to achieve social sustainability.

\begin{tabular}{|c|c|c|}
\hline \multirow[b]{2}{*}{ VDP-Triad * } & \multicolumn{2}{|c|}{ Social Sustainability as ... } \\
\hline & ... Individual Activation & ... Societal Equilibrium \\
\hline $\begin{array}{l}\text { Descriptions or } \\
\text { judgments of reality }\end{array}$ & $\begin{array}{l}\text { Descriptions on how changes } \\
\text { in the welfare system have } \\
\text { occurred from universal and } \\
\text { de-commodified social } \\
\text { services to more neoliberal } \\
\text { elements of individual choice. }\end{array}$ & $\begin{array}{l}\text { Descriptions on how of overall } \\
\text { societal processes-globalization, } \\
\text { digitalization, migration, } \\
\text { urbanization-affects social life. }\end{array}$ \\
\hline Value judgments & $\begin{array}{l}\text { Social sustainability should be } \\
\text { based on individual rights, } \\
\text { responsibility, and freedom of } \\
\text { choice. }\end{array}$ & $\begin{array}{l}\text { Social sustainability should be } \\
\text { based on an integrated approach; } \\
\text { an equilibrium among several } \\
\text { social values (security, justice, } \\
\text { human development). }\end{array}$ \\
\hline $\begin{array}{l}\text { Prescriptions or practical } \\
\text { proposals }\end{array}$ & $\begin{array}{l}\text { Policies for lifelong learning } \\
\text { career management, incentive } \\
\text { structures, coaching and } \\
\text { coping strategies towards } \\
\text { individuals. }\end{array}$ & $\begin{array}{l}\text { Policies for structural changes in } \\
\text { society concerning participative } \\
\text { democracy, liberal arts education, } \\
\text { reforms in the health care system, } \\
\text { creating "proventive security". }\end{array}$ \\
\hline
\end{tabular}

*In this study, we will switch the (V) with the (D) in the sequence and start the analysis with the descriptions, followed by the value judgments, and finally, the prescriptions.

\subsection{Step 3: Conclusion-What Is the Problem Represented to Be}

Finally, we will conclude the analysis by answering the main question in Bacchi's WPR-analysis. As noted above the task is-in the words of Carol Bacchi-in a 'WPR' analysis is to read

policies with an eye to discerning how the 'problem' is represented within them and to subject this problem representation to critical scrutiny (p. 21, [55]).

In the critical scrutiny in this study, we will present the main findings and answer the research question on what the problem is represented to be. In the concluding Section 5 , we will further problematize the implications of the empirical findings and in the discussion, we will mainly deal with the following issues related to the policy representation in our empirical case:

1. How is the problem represented in relation to the two ideal types: on individual activation or societal equilibrium? Is it possible to discern changes in the problem representation among different levels and actors in the implementation process?

2. What kind of character and assumptions prevail (concerning, for example, the policy content, the nature of the policy processes, the design of strategies and working methods)?

3. What are the silences that have been left unproblematic in the representation of the implementation process? Can the problem be thought of differently?

Hence, in the concluding section we will problematize various implications on how to introduce and implement policies supporting social innovations and social enterprises. In the final part, we will present some thoughts on future research.

\section{Analysis}

In this section, we will analyze how the involved actors articulate issues in the policy process at three levels. Firstly (Section 4.1), we make an analysis at the regional level based on articulations found in policy documents (the national strategy and the regional development strategy), conference documents (material presented at the kick-off conference), and in the application of the development project. Secondly (4.2), we make an analysis at the level of the project team based on articulations made in focus group interviews. Finally (4.3), we analyze the level of the social entrepreneurs based on articulations in the 
semi-structured interviews. Together, the different levels of analysis provide theoretical and empirical insights into the underlying premises, assumptions, and discourses at play when the policy area is put into practice from creation to implementation.

\subsection{The Regional Level-The Initial Formulation of the Policy Problem}

The primary impetus behind creating a policy for social innovations and social enterprises in the region can be linked to a publicly funded economic association that provides counselling information, training, and advice for starting cooperative enterprises and supports social entrepreneurship. The organization is structured via independent units in each region all over Sweden. The regional unit of the economic association operating in the southern part of Sweden has, at least since 2010, made several attempts to articulate the need for a comprehensive policy in business development concerning social innovations and social entrepreneurship. Similar to the development for the Nordic countries in general, these ambitions have been met by an interest in the region and some degree of resistance.

In the light of the fact that other counties have taken similar initiatives, the economic association took another initiative in 2016 by inviting potentially interested actors and stakeholders to a kick-off conference. Thus, this initiative was developed mainly by the public actors at the regional level, but a considerable interest was also shown by both for-profit and non-profit participants in the region. A broad range of organizations are invited from all sectors in society. About 50 people signed up, and the conference was attended by representatives from municipalities, state authorities, local action groups (within the EU Leader Program), the Church of Sweden, trade unions, environmental associations, sports clubs, business organizations, and small businesses. The conference included lectures and an exchange of experiences. During the conference, representatives from the economic association documented a rich canvas of needs and challenges for social innovations to address several societal challenges in the region. The presentations at the conference focused on issues such as climate change, work-integrating businesses, rural development, and health care (the documentation, all written in Swedish, can be provided by the corresponding author upon request).

The documentation from the conference forms the basis for continued work to initiate a regional policy. The regional organization led the continued activities in cooperation with the participation from mainly the university and the county council. The policy is concretized in 2017 by initiating a project to build an arena for knowledge, method testing, follow-up research, network building, and business development activities to develop social innovations and social entrepreneurship. The project, which attracted funding from the European Regional Development Fund, started at the beginning of 2018 and lasted until December 2020 (the application, written in Swedish, can be provided by the corresponding author). The intention was to help small businesses combine the logic of entrepreneurship to enhance social values. Examples of activities are:

- creating social innovation labs,

- awareness-raising activities (workshops, teaching conferences, study visits),

- design strategies for commercial development,

- individual coaching of entrepreneurs in starting or consolidating social enterprises.

When analyzing the material produced as a basis for both the conference and the project application, we can conclude that the description of societal development is articulated in terms of dealing with complex social challenges. It concerns issues such as the depopulation of rural areas, growing social exclusion, and climate change. However, some formulations on problems at the individual level, for example, notes on how to create possibilities for individual activation and responsibility. For example, this latter type of problem characterizes a large part of work-integrating social enterprises. The idea is to sell goods and services on the market with companies, often cooperatively organized. The basic idea is that the employees should receive help and support to adapt to working life. These may be people who have had difficulty getting work due to long-term sick leave or due to the integration of refugee immigrants in the labor market. The overall conclusion 
is that the documentation mainly describes structurally fixated problems. Thus, social innovations are initially motivated as developments in society and concern shortcomings in the societal systems. The development of the new policy area is so far following the strategy at the national level. The main focus is directed towards social sustainability as a societal equilibrium strategy.

Descriptions of the societal development during this initial phase are linked to a number of normative justifications of the policy problem. Several of the speakers at the kick-off conference stressed integrating multi-dimensional perspectives and values to accomplish societal changes. Particularly, this is the case in policies concerning rural development. The capacity to achieve long-term sustainability for rural communities should consider the importance of public services, conditions for private enterprises, infrastructure investments, protection of cultural heritage, and quality of life. This joined perspective also characterizes normative justifications in climate change adaptation that underline processes of integration and coordination both within and across policy areas and organizational levels in society.

Again, to be regarded as a minor part, there are normative values that focus on the responsibility of each individual to reduce various forms of social exclusion. However, it is worth adding that social exclusion is not only analyzed as an individual responsibility but also as a part of shortcomings in the overall social system. Social exclusion is then analyzed as failures in coordinating social investments, for example, housing refurbishment, infrastructure, health initiatives, recreation, and cultural activities. The conclusion is that social exclusion is not primarily due to passivated and benefit-dependent individuals but to poorly developed social institutions.

Against this background, it can be noted that when the new policy is initiated, led by the regional organization, it is explicit that it should primarily address societal changes. However, some elements in the policy initiation emphasize social sustainability based on the responsibilization of individuals, but these are subordinate. The dominant part concerns the lack of institutional arrangements, resources, and support structures to support individuals and organizations that want to invest in social innovations. The policy problem represents intentions to create an institutionalized arena to change and improve conditions for positive social change. One essential part of the policy idea is to give public attention to a bias in that business counseling systems often disregard social innovation and social enterprises.

Consequently, a basic principle in the policy idea is to assert the particularities that characterize positive social change in business policy. The particularity consists of the fact that social innovations aim to achieve structural conditions concerning long-term sustainability. Again, we can note that these conclusions, articulated in the conference materials and the project application, are linked to the strategy at the national level-both in creating an arena and strengthening efforts for active counselling supporting initiatives in starting social enterprises.

If we summarize the analysis so far, we can conclude that the original policy representation is based on an idea to strengthen the institutional capacity in the region to support sustainable forms of social innovations and social entrepreneurship. Although there are activities in the development project that aim to assert a commercial focus and also the need for individual activation, the policy problem is mainly represented to be an issue anchored in a societal context.

\subsection{The Level of the Project Team}

When the development project started in January 2018, a project team was formed: a Project manager, a Business Coach, and an Administrator. It is also worth noting that the Project Owner (as a director for the economic association responsible for the project) takes an active part in planning and implementing the project as a regular discussion partner to the project team. During the focus group interviews with the project team (including the project owner), a partially changed representation of the problem could be 
identified. The main focus is gradually displaced from a societal orientation to growing attention on problems associated with the individual entrepreneur and the participants' entrepreneurial mindset.

Thus, we can see tendencies towards a policy shift that become clear in two respects and can also be described as policy dilemmas. Firstly is a dilemma linked to how the project team selects participating entrepreneurs. When the project team describes the selection process, the ambition is to find a segment of entrepreneurs who do not usually seek out the existing support structure. This mainly applies to local business offices, regional actors, incubators, and institutions for the supply of venture capital.

This means that the project primarily addresses a segment of entrepreneurs who have a weak interest and scarce resources in creating new businesses. It should be said that this is a well-considered and strategic choice in the project. Characteristically, this implies that many of the selected entrepreneurs have difficulties accessing various forms of institutional support. Although the project team is aware of the importance of maintaining a clear societal orientation in the project, efforts are required to train the recruited participants for individual responsibility and changed attitudes. The project team has to spend a lot of time and resources on coaching individual participants to develop their social enterprising efforts with a commercial and market-oriented mindset. The risk is that this will lead to a policy shift; the policy problem is to a lesser extent directed towards sustainability in a societal perspective and increasingly towards problems linked to each entrepreneur.

Secondly, we can identify a policy shift in a dilemma associated with the tools and methods utilized in project-making business counseling activities. Often, these tools have been developed to suit traditional business counselling and are not specially designed for developing social businesses. For example, one of these tools or models-called the Business Development Matrix - is sequentially based on business development, emphasizing goal-oriented considerations of the individual entrepreneur and his/her relations to the market, the customers, budgeting, and business acumen.

The project team has made conscious attempts to adapt the tools to managing social enterprise and launched several modifications for this purpose. However, existing tools for business development are foremost based on traditional entrepreneurship. They are subsequently modified to contain at least some aspects to consider social or societal elements. However, it is not the other way around, i.e., that social enterprise forms the basis and is then modified with elements of commercially and individually oriented activities. The difficulties of adapting the available tools for business development with a social and system-changing purpose have been a central challenge for the project team. In addition, in this part, there is a risk that the tools contribute to a shift of the policy representation from a societal focus to thinking characterized by the activation and responsibility of the individual entrepreneur.

The members of the project team express an intention to work for an institutionalized arena for the development of social innovations and social enterprise in the region. In this part, the argument is mainly taken from the project application. The arguments emphasize a need to create structure and visibility for this work in the future. Thus, the project team has worked intensively to establish this arena, mainly to find a venue or place as a unifying base for the activities. The project team claims the need for a common entrance for actors with ideas about developing social innovations. As the work with the project has started, it has become even more evident that this kind of counselling is dependent on personal meetings in real life. Several of the members of the project team emphasize the importance of the exchange of experience on-site in an everyday context. The need to create an institutionalized arena is also motivated because it can be a collective resource for disseminating information, conducting learning activities, and documenting experiences. The argument for the arena is thus linked to the uniqueness that characterizes social innovations compared to other kinds of business counselling. 


\subsection{The Level of the Social Entrepreneurs}

Finally, the views of the participating entrepreneurs have been analyzed. A total of 35 participants have received support through the initiatives implemented in the development project. Therefore, we can categorize the participating entrepreneurs into two main categories. The first, which dominates (about $80 \%$ of all), focuses exclusively on individuals as a target group. The second category may also have individuals in focus but have a more substantial element of a societal orientation in their entrepreneurship ideas compared to the first category.

In the first category, where many of the business ideas are similar to each other, the description of reality is fixed on the health and well-being of individuals. The policy problem to be solved is developing attitudes and tools to change people's life situations through individual activation. The tools are intended to influence responsibility and interest in changing their own lives, becoming more harmonious as human beings, dealing with drug problems or gambling addictions, getting out of destructive relationships, etc. The characteristic of this group of entrepreneurs is that they have difficulties describing the significance of their business idea from a societal or social perspective. During the interviews, one continuously returns to challenges in the individual context; therapeutic methods, coping linked to stress management, mindfulness, individual rehabilitation, cultural experiences, etc. The interviewed entrepreneurs have in-depth knowledge and competence in their specialization, often highlighting their personal experiences of the specific problems they want to work on within their enterprise. However, the participating entrepreneurs often lack insights and skills in running a business and conducting it in a business-like way. Commitment is strong on the issues, but the ability to write a business plan, create long-term financing, and manage marketing is not as well developed. The observations made by the project team are that the entrepreneurs have difficulties in running companies with financial viability also appears in our interviews.

In the second category of participants, where we can discern a societal or social orientation, the description of reality is based on a given societal problem. These statements are mainly linked to climate issues in our material, but individual entrepreneurs point to shortcomings in the food supply, issues concerning developing countries, and depopulation in rural areas. In this category, the need for social innovations is justified from a structural perspective and ideas about long-term societal development. However, it should be noted that these constitute a minority among participating entrepreneurs and that there is also a connection among them to individual activation and responsibilization. In this group, however, we can find a more developed and well-thought-out perspective on what is meant by social change compared to how it is in the first category.

We can conclude that there is a minority who intends to develop their future business with a dominant normative notion of being able to influence societal structures among the participants. The dominant group of entrepreneurs is driven by perceptions that primarily contribute to the development of the individual. The participants generally find it difficult to see themselves as "social" entrepreneurs. Instead, they regard themselves as committed human beings with ambitions to run a business. When a large proportion of the participating entrepreneurs work to help individuals get out of their problems, a dilemma immediately arises about running a profitable company at all.

This kind of problem is linked to the type of entrepreneurship that should be the target group to stimulate social innovation and social enterprise. When selecting potential participants who has a predominance of entrepreneurship linked to individual activation, there is a risk of losing the societal dimension. This can then be related to the selection problem that was touched on above about the strategy of the project team to find entrepreneurs who do not fit well into the established support and advisory system for business development in the region.

Regarding the question of what the entrepreneurs want in terms of policy proposals in the future, attention is drawn to the need to continue to receive support to develop their companies. The interviewed entrepreneurs make several suggestions. Many articulate the 
importance of building networks and, together with other entrepreneurs, create a common platform for cooperation on a reciprocal basis. The project experiences are generally valued positively as they have entered into a collaboration and exchange of experience with other entrepreneurs. Even if you work with different subject areas and varying forms of enterprises, many problems are common. Many interviewees would like to see an established arena for continued exchange and opportunities for continuous advice. There is a call for support to apply for project funding, develop their marketing, get help with contact-creating with other support organizations, etc. The interviewees highlight various needs for support measures. Undoubtedly, the group of active entrepreneurs is interested in developing an arena for social innovation in the region. The interviewed participants emphasize that the arena has a task primarily to support the entrepreneurs in practical parts, such as financing, marketing, and exchange of experience.

\subsection{Concluding Analysis}

In this section we have answered the three sub-questions that was raised in the introduction, which is summarized in Table 3:

- In what ways are societal reality characterized in the policy representation?

- What normative assumptions underpin the representation?

- How has the representation of the problem been transformed to policy proposals?

Table 3. Main findings from analysis.

\begin{tabular}{|c|c|c|c|}
\hline Level of Analysis/Material & Descriptions of Reality & Normative Justification & Policy Guidelines \\
\hline $\begin{array}{l}\text { The regional level } \\
\text { - pre-evaluation report } \\
\text { - kick-off conference } \\
\text { - project application }\end{array}$ & $\begin{array}{l}\text { Overall societal processes } \\
\text { such as urbanization, climate } \\
\text { change, integration, } \\
\text { unemployment. }\end{array}$ & $\begin{array}{l}\text { A society that is able to utilize } \\
\text { social commitments in civil } \\
\text { society in developing public } \\
\text { policies for social change. }\end{array}$ & $\begin{array}{l}\text { The need for an institutional } \\
\text { arena to create identity and to } \\
\text { visualize the specificity of } \\
\text { social innovations. A need to } \\
\text { weigh in between social } \\
\text { sustainability and social } \\
\text { investments. }\end{array}$ \\
\hline $\begin{array}{l}\text { The project team } \\
\text { - focus-group interviews }\end{array}$ & $\begin{array}{l}\text { Identification of a segment of } \\
\text { individuals and organizations } \\
\text { in society that get no attention } \\
\text { in public policies for business } \\
\text { development. }\end{array}$ & $\begin{array}{l}\text { To expand the opportunities } \\
\text { for social change through } \\
\text { ideas about entrepreneurship } \\
\text { and social innovations }\end{array}$ & $\begin{array}{l}\text { The need for an institutional } \\
\text { arena to create networks to } \\
\text { enhance business counselling } \\
\text { especially among social } \\
\text { entrepreneurs }\end{array}$ \\
\hline $\begin{array}{l}\text { Social entrepreneurs } \\
\text { - semi-structured interviews }\end{array}$ & $\begin{array}{l}\text { Focused on problems of social } \\
\text { exclusion among individuals. }\end{array}$ & $\begin{array}{l}\text { Social change is dependent on } \\
\text { the degree of conscious and } \\
\text { responsible activities among } \\
\text { individuals. Individual } \\
\text { activation per se. }\end{array}$ & $\begin{array}{l}\text { The need for an institutional } \\
\text { arena to support newly } \\
\text { started enterprises in practical } \\
\text { issues concerning economic } \\
\text { strategies }\end{array}$ \\
\hline
\end{tabular}

For all three questions, we can note critical differences between the three levels of analysis. First, on descriptions of reality, different views are articulated between all three levels. Articulations made at the regional level on overall societal processes are not exposed among the articulations made by the project team or among the participating entrepreneurs. The project team is mainly occupied by descriptions of which actors usually do not utilize public business counseling policies. The project team identifies several aspects of society that substantially restrain the options for potential entrepreneurs with social ambitions to start businesses. The policy shift is due to the task given to the project team, namely, to support the ability of individual entrepreneurs to create new social businesses.

Among the participating entrepreneurs, the perspective is, to a large extent, linked to the difficulties individuals may encounter in society. As a result, the descriptions are almost exclusively fixed to social problems among individuals. With some exceptions, the interviewees are not expressing any views that problematize overall societal processes, 
such as the depopulation of rural areas or structural unemployment, to explain existing social problems among individuals.

In the second category, we can find similarities between the regional and project teams on normative justifications. The articulations circle around the need to utilize and visualize ideas and commitments to develop social innovations in society. Social involvement in society should be linked to policy ambitions in creating entrepreneurship and business development. On both levels, the actors are well informed on social innovation as a globally disseminated policy concept. In important respects, the articulations are inspired by national as well as global initiatives. However, there is an entirely differing normative justification among the participant entrepreneurs, entirely based on individual activation. Undoubtedly, this is the most apparent policy shift in the analysis. The normative understanding of developing social innovations is not rooted among the participating entrepreneurs.

In the third column on policy guidelines, there is a difference in articulations between, on the one hand, the regional policy level and, on the other, the project team and the participating entrepreneurs. At the regional level, the policy guidelines focus on establishing an arena that could be recognized and visualized in the regional policy context. The policy idea consists of asserting the importance of social innovations as a part of strategies in the regional development policy in the region. It should be seen as a political proposal in the region to introduce social sustainability as an area of innovation. At the project team level and among participants, the policy guidelines proposed assert the need for practical tools to create networks among social businesses, seminars, learning activities, etc.

Finally, the analysis findings indicate significant changes in the policy representation when moving from the top to the bottom. The conclusion is that the intentions formulated at the regional level and in the project application have become something partly different during the implementation of processes and activities at the lower levels in the implementation chain. In the concluding section below, we will delve a little further into this conclusion.

\section{Discussion and Conclusions}

In policy declarations from governments and influential NGOs worldwide, social innovations are seen as necessary and useful ways of managing most of the contemporary social challenges in our common world. This article has turned into the microcosm of creating social innovations and supporting social enterprise in a small region in Sweden. Even in this microcosm, great hopes are attached to social innovations that will address social challenges in society.

During the work on this study, we have continuously been met by a strong commitment among participating entrepreneurs to personally contribute to creating improved living conditions for socially disadvantaged people. As several researchers have pointed out, the policy area is characterized by a distinctive and sometimes conflict-ridden confusion of business acumen as well as well-founded humanism [18]. Thus, we agree with the conclusion made by several scholars that we need to make in-depth analyzes of what characterizes the individual entrepreneurs in their efforts to develop social enterprises [26].

Our analyses provide an in-depth understanding of several critical issues in international research on social innovations. In our study, activities in the policy area are part of a hybridized organizational field between public, civil, and private sectors. Often, the development processes contain ideologically based value conflicts. The main conclusion is that we have found that basic policy values are shifted in the policy process's different phases. We have also shed light on shifting attitudes concerning organizing and developing the support structure for social innovation at the regional level. Thus, issues related to policy processes rather than policy content tend to dominate during the implementation. In the following, the intention is to summarize the analysis and answer the research questions.

Then, what is the problem represented to be in our case? Our analysis indicates that the original problem representation shifted as the activities in the project were imple- 
mented. During the initial phase, the policy idea consisted of well-considered ambitions to create long-term sustainable development. However, during the implementation of the project, the problem's representation changes gradually in the direction towards individual activation and responsibility. This process is driven by pragmatic difficulties of defining the policy area, problems of separating means from ends, and the need to make decisions based on a limited range of information and analysis to get things going. Hence, at the project level, the gradual change in coping with the contradictions and multiple complexities facing activities in a dynamic and complex policy area. In this respect, the reformulation of the problem enables the project team to meet project goals and produce legitimacy towards beneficiaries. However, it also means that ambitions expressed in original policy representations become altered where calls for more profound change in institutional regimes transform into more adaptive, performance-related social innovation efforts [20].

The reformulation of the problem occurs when strategies concerning the selection of entrepreneurs for the activities in the project are formulated. Current policies supporting innovation in the region are identified as having a weak support structure for entrepreneurs who have a solid social commitment but lack the abilities and knowledge to start and run businesses. Therefore, the developed strategy is to prioritize entrepreneurs who are not usually part of the support structure within business and growth policies. Thus, the entrepreneurs who participate in the project are driven by business ideas that, in many cases, lack immediate commercial potential and are often strongly linked to personal interest and commitment.

In sum, the conclusion in this part indicates that the policy area has so far been weakly institutionalized. The involved actors in the implementation structures are given high discretion to design their principles and working methods. As a result, policy intentions and decisions weakly guide those who implement the policy.

\subsection{Implications}

Our study has implications in a number of areas. The findings illustrate the potential friction created when deeply embedded normative principles connected to collective orientations and social welfare meet the individualized and incentive-driven systems that characterize the support structures for fledging entrepreneurs. In this process, the project receives a focus that emphasizes both individual coaching among the involved entrepreneurs and a commitment among the entrepreneurs to support rehabilitation among individuals. This implies that the original policy ambition to adopt market mechanisms to long-term social sustainability principles is silenced in favour of social sustainability as individual activation in a market perspective. In other words, the implementation process tends to repeatedly emphasize principles that social sustainability should be developed using market mechanisms rather than the other way around - that the market economy needs an underlying logic based on long-term social sustainability. In this respect, our analysis pinpoints the "mission impossible" at the project level and where the pragmatic challenges of the social ventures favour an individual activation strategy.

Another kind of silenced policy representation concerns the idea of creating a regional arena promoting social innovations and social enterprises in the region. The original policy idea was formulated as an arena to institutionalize and visualize a long-term political commitment to developing a new policy area. Following the policy shift noted above, the arena is gradually redefined to become a specific site to deal with practical problems related to the needs of the individual entrepreneur-a kind of hub and lab for managing everyday problems. It also means that the arena is losing its political significance as a negotiation network among leading actors from the public, private, and civil sectors in the region.

For example, our participatory observations in this study give a strong impression that there is a lack of consideration among leading actors on what is social in the policy representation. There are few or no conflicts over the formulation of the representation. Moreover, we have so far been able to notice any debate in public spaces or the media. The political parties are absent in the development processes taking place around our 
case. Correspondingly, significant influence has been placed on officials and experts in implementing the policy.

Moreover, the implementation of projects and measures needs to assert the social dimension in the policy area. Social enterprising efforts are closely linked to processes of restructuring welfare states who are under the pressure to innovate to meet increasing demands of social services $[14,56]$. It is, however, clear from the empirical material that there are several different perceptions. The selection process, methods/tools, and business plans deal with making visible the issues of wicked problems, institutional structures, and balancing various aspects holistically. Few participants put heavy emphasis in addressing entrepreneurial activities from a societal perspective or supporting ideas of a social sustainable society. The analysis presented in this article thus stresses the need to clarify what is meant by the prefix 'social' in the policy area.

The depoliticization of the implementation process could create a policy representation that is foremost a rhetorical or symbolic figure whose primary purpose is to build a consensus among leading policy actors. The conditions for establishing an institutionalized implementation structure are weakened, and the initiated activities, which are often valued positively by project owners and participants, risk running out and coming to nothing after the project ends. If one refers to anything other than individual activation when developing social sustainability policies, this should include a more activated political leadership. In this case, creating an institutionalized arena is a window of opportunity for building long-term continuity in the implementation processes and as a political forum for policy development with a longer time perspective.

\subsection{Limitations and Future Research}

We need to acknowledge the methodological limitations in this study. The method used in this study, i.e., qualitative analysis in one case, belongs to the category that has dominated the research field. Because of the dynamic and complex nature of the area, there is a need for broadening the methodological "toolbox" by theory development and the use of multiple, mixed, and iterative empirical methods in the future. [57-59]. Moreover, our study relied on interviews and participatory observations as the primary method of data collection. Even if this has enabled us to stay close to the lived experience of the informants, we also acknowledge the risk of our data being susceptible to social desirability bias. Adding to this, the study is conducted in Sweden, a country that combines a solid tax-funded welfare system with a relatively well-developed support structure for aspiring entrepreneurs. Thus, comparative analyses on policy implementation in different socioeconomic and political contexts using cases from other countries are recommended to corroborate and contextualize our findings.

Finally, we make a brief note on issues requiring further research and investigation. Along this line, there is a need for further research to deepen the understanding of how strategies for social innovations and social enterprise include issues concerning how the social dimension is defined. Not least, there is a lack of studies of how the policy area can be linked to ambitions for social sustainability [60-62]. Moreover, as has been mentioned above, we see great potential in comparative research designs by conducting studies of multiple social innovation projects across different regional settings. This would be particularly useful for understanding and explaining how the broader policy context influences the implementation of social innovation projects. Finally, we encourage studies with even longer time spans. Creating and implementing weakly institutionalized policy areas can be a slow and incremental process. However, such initiatives may over time contribute to policy learning that gradually increase the systemic understanding of the implementation and effects of project based and other coordinated efforts to meet social challenges in the region. Following how this learning process emerges and unfolds at various levels would provide great contributions to our knowledge of social innovations as a policy area. 
Author Contributions: Conceptualization, J.J. and J.G.; methodology, J.G. and J.J.; writing-original draft preparation, J.J. and J.G.; writing-review and editing, J.G. and J.J. Both authors have read and agreed to the published version of the manuscript.

Funding: This research was funded by The European Regional Development Fund.

Informed Consent Statement: Informed consent was obtained from all subjects involved in the study.

Data Availability Statement: The data presented in this study are available on request from the corresponding author.

Conflicts of Interest: The authors declare no conflict of interest.

\section{References}

1. OECD. Fostering Innovation to Address Social Challenges; OECD: Paris, France, 2011.

2. European Commission (EC). Social Innovation Research in the European Union. Approaches, Findings and Future Directions-Policy Review Brussels: D-G Research and Innovation; EC: Brussels, Belgium, 2013.

3. European Commission (EC). Social Enterprises and their Ecosystems: Developments in Europe; EC: Brussels, Belgium, 2016.

4. Nicholls, A. Social Enterprise and Social Entrepreneurs. In The Oxford Handbook of Civil Society; Oxford University Press: Oxford, UK, 2011.

5. Barlagne, C.; Melnykovych, M.; Miller, D.; Hewitt, R.; Secco, L.; Pisani, E.; Nijnik, M. What Are the Impacts of Social Innovation? A Synthetic Review and Case Study of Community Forestry in the Scottish Highlands. Sustainability 2021, 13, 4359. [CrossRef]

6. Mulgan, G. Social Innovation: How Societies Find the Power to Change; Policy Press: Bristol, UK, 2019.

7. Grimm, R.; Fox, C.; Baines, S.; Albertson, K. Social innovation, an answer to contemporary societal challenges? Locating the concept in theory and practice. Innov. Eur. J. Soc. Sci. Res. 2013, 26, 436-455. [CrossRef]

8. Howaldt, J.; Kaletka, C.; Schröder, A.; Zirngiebl, M. (Eds.) Atlas of Social Innovation: 2nd Volume: A World of New Practices; Oekom Verlag: München, Germany, 2019.

9. Kerlin, J.A. Defining Social Enterprise Across Different Contexts: A Conceptual Framework Based on Institutional Factors. Nonprofit Volunt. Sect. Q. 2013, 42, 84-108. [CrossRef]

10. Komatsu, T.; Deserti, A.; Rizzo, F.; Celi, M.; Alijani, S. Social Innovation Business Models: Coping with Antagonistic Objectives and Assets. In Finance and Economy for Society: Integrating Sustainability; Emerald Group Publishing Limited: Bingley, UK, 2016; Volume 11, pp. 315-347.

11. De Pieri, B.; Teasdale, S. Radical futures? Exploring the policy relevance of social innovation. Soc. Enterp. J. 2021, 17, 94-110. [CrossRef]

12. Van der Have, R.; Rubalcaba, L. Social innovation research: An emerging area of innovation studies? Res. Policy 2016, 45, 1923-1935. [CrossRef]

13. Edwards-Schachter, M.; Wallace, M.L. 'Shaken, but not stirred': Sixty years of defining social innovation. Technol. Forecast. Soc. Chang. 2017, 119, 64-79. [CrossRef]

14. Defourny, J.; Lars, H.; Pestoff, V. Social Enterprise and the Third Sector: Changing European Landscapes in a Comparative Perspective; Routledge: New York, NY, USA, 2014.

15. Gawell, M. Activist Entrepreneurship: Attac'ing Norms and Articulating Disclosive Stories. Ph.D. Thesis, School of Business, Stockholm University, Stockholm, Sweden, 2006.

16. Jensen, H.; Björk, F.; Lundborg, D.; Olofsson, L.E. An Ecosystem for Social Innovation in Sweden: A Strategic Research and Innovation Agenda; Institute for Educational Sciences, Lund University: Lund, Sweden, 2014.

17. Boudes, M. Social Innovation: From hybridity to purity through ambivalent relations to institutional logics. Acad. Manag. Proc. 2016, 2016, 15564. [CrossRef]

18. Mulgan, G.; Tucker, S.; Ali, R.; Sanders, B. Social Innovation: What It Is, Why It Matters and How It Can Be Accelerated; Saïd Business School: Oxford, UK, 2007.

19. Lundgaard Andersen, L.; Gawell, M.; Spear, R. (Eds.) Social Entreprenuership and Social Enterprises in the Nordics: Narratives Emerging from Social Movements and Welfare Dynamics. In Social Entreprenuership and Social Enterprises: Nordic Perspectives; Routledge: New York, NY, USA; London, UK, 2016.

20. Perlik, M. Impacts of Social Innovation on Spatiality in Mountain-Lowland Relationships-Trajectories of Two Swiss Regional Initiatives in the Context of New Policy Regimes. Sustainability 2021, 13, 3823. [CrossRef]

21. Dahlstedt, M. Discourses of employment and inclusion in Sweden. In Social Transformations in Scandinavian Cities: Nordic Perspectives on Urban Marginalization and Social sustainability; Johansson, E.R., Salonen, T., Eds.; Nordic Academic Press: Lund, Sweden, 2015.

22. Abrahamsson, H. The great transformation of our time. Towards just and socially sustainable Scandinavian cities. In Social Transformations in Scandinavian Cities: Nordic Perspectives on Urban Marginalization and Social Sustainability; Johansson, E.R., Salonen, T., Eds.; Nordic Academic Press: Lund, Sweden, 2015.

23. Bacchi, C. Policy as Discourse: What does it mean? Where does it get us? Discourse: Stud. Cult. Politics Educ. 2000, 21, 45-57. [CrossRef] 
24. Choi, N.; Majumdar, S. Social entrepreneurship as an essentially contested concept: Opening a new avenue for systematic future research. J. Bus. Ventur. 2014, 29, 363-376. [CrossRef]

25. Ferreira, J.J.; Fernandes, C.I.; Peres-Ortiz, M.; Alves, H. Conceptualizing social entrepreneurship: Perspectives from the literature. Int. Rev. Public Nonprofit Mark. 2017, 14, 73-93. [CrossRef]

26. Saebi, T.; Foss, N.J.; Linder, S. Social Entrepreneurship Research: Past Achievements and Future Promises. J. Manag. 2019, 45, 70-95. [CrossRef]

27. García-Jurado, A.; Pérez-Barea, J.J.; Nova, R. A new approach to social entrepreneurship: A systematic review and meta-analysis. Sustainability 2021, 13, 2754. [CrossRef]

28. Phills, J.A.; Deiglmeier, K.; Miller, D.T. Rediscovering Social Innovation. Stanf. Soc. Innov. Rev. 2008, 6, $34-43$.

29. Littlewood, D.; Khan, Z. Insights from a systematic review of literature on social enterprise and networks. Soc. Enterp. J. 2018, 14, 390-409. [CrossRef]

30. Littlewood, D.; Holt, D. Social Entrepreneurship in South Africa: Exploring the Influence of Environment. Bus. Soc. 2018, 57, 525-561. [CrossRef]

31. Murray, R.; Caulier-Grice, J.; Mulgan, J. The Open Book of Social Innovation; Social Innovators Series; The Young Foundation: London, UK, 2010.

32. Austin, J.; Stevenson, H.; Wei-Skillern, J. Social and Commercial Entrepreneurship: Same, Different, or Both? Entrep. Theory Pract. 2006, 30, 1-22. [CrossRef]

33. Mair, J.; Martí, I. Social entrepreneurship research: A source of explanation, prediction, and delight. J. World Bus. 2006, 41, 36-44. [CrossRef]

34. Hull, C.E.; Lio, B.H. Innovation in non-profit and for-profit organizations: Visionary, strategic, and financial considerations. J. Chang. Manag. 2006, 6, 53-65. [CrossRef]

35. Ezponda, J.E.; Malillos, L.M. A Change of Paradigm in the Study of Innovation: The Social Turn in the European Policies of Innovation. Arbor Cienc. Pensam. Cult. 2011, 187, 1031-1043. [CrossRef]

36. Massey, A. Governance: Public governance to social innovation? Policy Politics 2016, 44, 663-675. [CrossRef]

37. Parrilla-González, J.; Ortega-Alonso, D. Social Innovation in Olive Oil Cooperatives: A Case Study in Southern Spain. Sustainability 2021, 13, 3934. [CrossRef]

38. Lundgaard Andersen, L.; Hulgård, L. Social entrepreneurship: Demolition of the welfare state or an arena for solidarity. In Social Entrepreneurship and Social Enterprises: Nordic Perspectives; Routledge: New York, NY, USA; London, UK, 2016.

39. Defourny, J.; Nyssens, M. The EMES Approach of Social Enterprise in a Comparative Perspective. In EMES European Research Network; Routledge: London, UK, 2012.

40. Gawell, M. Societal Entrepreneurship and Different Forms of Social Enterprises. In Social Entrepreneurship: Leveraging Economic, Political, and Cultural Dimensions; Lundström, A., Zhou, C., von Friedrichs, Y., Sundin, E., Eds.; Springer International Publishing: Cham, Switzerland, 2014.

41. Lundström, A.; Zhou, C.; von Friedrichs, Y.; Sundin, E. (Eds.) Social Entrepreneurship. Leveraging Economic, Political, and Cultural Dimensions; Springer International Publishing: Cham, Switzerland, 2014.

42. Dees, J.G. Taking social entrepreneurship seriously. Society 2007, 44, 24-31. [CrossRef]

43. Kostilainen, H.; Pättiniemi, P. Evolution of the social enterprise concept in Finland. In Social Entrepreneurship and Social Enterprises: Nordic Perspectives; Routledge: London, UK, 2016.

44. Gawell, M. Social Enterprises and Their Ecosystems in Europe-Country Report: Sweden; Publications Office of the European Union: Luxembourg, 2019.

45. Gawell, M.; Lindberg, M.; Neubeck, T. Innovationslabb för Social Inkludering. Ideell Arena: Erfarenheter från Vinnova Finansierade Project. Available online: https:/ / idealistas.se/bocker/kommande-innovationslabb-for-social-inkludering (accessed on 15 July 2021).

46. Regeringens Strategi för sociala Företag-Ett Hållbart Samhälle Genom Socialt Företagande och Sociala Innovationer; M.o. Enterprise: Stockholm, Sweden, 2018.

47. Bacchi, C.L. Analysing Policy: What's the Problem Represented to Be? N.S.W. Pearson: Frenchs Forest, UK, 2009.

48. Bacchi, C.; Bonham, J. Reclaiming discursive practices as an analytic focus: Political implications. Foucault Stud. 2014, 173-192. [CrossRef]

49. Lundquist, L. Implementation Steering: An Actor-Structure Approach; Studentlitteratur: Lund, Sweden, 1987.

50. Barberis, P. Thinking about the state, talking bureaucracy, teaching public administration. Teach. Public Adm. 2012, 30, 76-91. [CrossRef]

51. Lindberg, M. Qualitative Analysis of Ideas and Ideological Content. In Analyzing Text and Discourse: Eight Approaches for the Social Sciences; Boréus, K., Bergström, G., Eds.; Sage: London, UK, 2017.

52. Jacobsson, K.; Hollertz, K.; Garsten, C. Local worlds of activation: The diverse pathways of three Swedish municipalities. Nord. Soc. Work. Res. 2017, 7, 86-100. [CrossRef]

53. Abrahamsson, H. Cities as nodes for global governance or battlefields for social conflicts? The role of dialogue in social sustainability. In Proceedings of the IFHP 56th World Congress: Inclusive Cities in a Global World, Gothenburg, Sweden, 16-19 September 2012.

54. Marmot, M. Social determinants of health inequalities. Lancet 2005, 365, 1099-1104. [CrossRef] 
55. Bacchi, C. Introducing the 'What's the Problem Represented to be?' approach. In Engaging with Carol Bacchi: Strategic Interventions and Exchanges; Bletsas, A., Beasley, C., Eds.; University of Adelaide Press: Aelaide, Australia, 2012.

56. Clark, K.D.; Newbert, S.L.; Quigley, N.R. The motivational drivers underlying for-profit venture creation: Comparing social and commercial entrepreneurs. Int. Small Bus. J. Res. Entrep. 2018, 36, 220-241. [CrossRef]

57. Kaletka, C.; Schröder, A. A Global Mapping of Social Innovations: Challenges of a Theory Driven Methodology. Eur. Public Soc. Innov. Rev. 2017, 2, 78-92. [CrossRef]

58. Wittmayer, J.M.; Pel, B.; Bauler, T.; Avelino, F.; De Bruxelles, U. Editorial Synthesis: Methodological Challenges in Social Innovation Research. Eur. Public Soc. Innov. Rev. 2017, 2, 1-16. [CrossRef]

59. Granados, M.L.; Hlupic, V.; Coakes, E.; Mohamed, S. Social enterprise and social entrepreneurship research and theory. Soc. Enterp. J. 2011, 7, 198-218. [CrossRef]

60. Rinkinen, S.; Oikarinen, T.; Melkas, H. Social enterprises in regional innovation systems: A review of Finnish regional strategies. Eur. Plan. Stud. 2016, 24, 723-741. [CrossRef]

61. Asenova, D.; Damianova, Z. The interplay between social innovation an sustainability in the Casi and other FP7 projects. In Atlas of Social Innovation-New Practices for a Better Future; Howaldt, J., Kaletka, C., Schröder, A., Zirngiebl, M., Eds.; SoziAlforschungsstelle, TU Dortmund University: Dortmund, Germany, 2018.

62. Young, D.R.; Searing, E.A.M.; Brewer, C.V. The Social Enterprise Zoo: A Guide for Perplexed Scholars, Entrepreneurs, Philan-Thropists, Leaders, Investors and Policymakers; Edward Elgar Publishing: Cheltenham, UK, 2018. 